\title{
SUBROGATION IN THE REAR-VIEW: \\ EVAluating Alberta's CURRENT APPROACH TO AUTOMOBILE LIABILITY INSURANCE FOR IMPAIRED DRIVERS
}

\author{
KENDAL GUMMER*
}

In Alberta, automobile insurers are required to indemnify an insured up to policy limits for injury or property damage to third parties for which the insured is liable. Prior to 1 June 1982, insurers could demand reimbursement for third party liability payments if the insured driver caused loss while under the influence of drugs or alcohol. However, the Insurance Amendment Act removed the right of insurers to recover these sums. This article evaluates this amendment by considering its impact on the public policy objectives ordinarily associated with subrogation, and argues that, compared to the previous approach, Alberta's current system of third party liability coverage better serves the objectives of subrogation.
En Alberta, les compagnies d'assurance-automobile doivent indemniser l'assuré jusqu'à concurrence du montant de la garantie pour les blessures corporelles ou matérielles à autrui dont l'assuré est responsable. Avant le $1^{\text {er }}$ juin 1982, les compagnies d'assurance pouvaient demander le remboursement de versements effectués pour la responsabilité civile si l'assuré avait causé la perte pour conduite avec facultés affaiblies par l'alcool ou des drogues. Cependant, la Loi modifiant la loi sur les assurances (Insurance Amendment Act) a retiré le droit des assureurs de récupérer ces sommes. Cet article évalue l'amendement en examinant son effet sur les objectifs des politiques gouvernementales normalement associées à la subrogation. L'auteur fait valoir que, comparativement à la démarche précédente, le système de responsabilité civile actuellement en vigueur en Alberta convient mieux aux objectifs de la subrogation.

\section{TABLE OF CONTENTS}

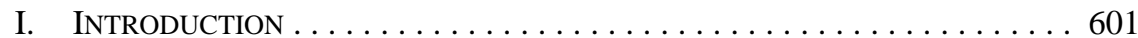

II. PARAMETERS OF THIS DISCUSSION . . . . . . . . . . . . . . . . . . . . . . 603

III. THE FirST OBJECTIVE OF SUBROGATION:

ENSURING COMPENSATION FOR VICTIMS . . . . . . . . . . . . . . . . 604

IV. The SECOND OBJeCtive OF SUbROGATION:

SHIfTING THE LosS to the Wrongdoer $\ldots \ldots \ldots \ldots \ldots \ldots \ldots$

V. THE THIRD OBJECTIVE OF SUBROGATION:

REDUCING THE COST OF INSURANCE . . . . . . . . . . . . . . . . . . . . . 614

VI. CONCLUSION ................................6 617

\section{INTRODUCTION}

The significance of the impaired driving problem in Canada cannot be overemphasized. Between 2000 and 2009, there were an estimated 2,020,719 motor vehicle accidents across the country involving alcohol and drugs. ${ }^{1}$ The result was a staggering 703,604 injuries and

BSc with distinction and JD with distinction, University of Alberta; student-at-law with McLennan Ross LLP in Calgary. The author is grateful to Professor Barbara Billingsley of the University of Alberta Faculty of Law for her valuable feedback throughout the writing process.

$1 \quad$ Stephen Pitel \& Robert Soloman, "Estimating the Number and Cost of Impairment-Related Traffic Crashes in Canada: 1999 to 2010" (April 2013), online: MADD Canada <http://www.madd.ca/english/ research/estimating_presence.pdf> at 8-9 (to generate a figure for the period of 2000-2009, the estimated number of impairment related crashes in the year 1999 was subtracted from the total in Table 5). 
11,922 deaths. ${ }^{2}$ Approximately 2,025 of these deaths occurred on Alberta's roads. ${ }^{3}$ Over this ten year period, the province failed to significantly reduce its rate of impairment-related crash deaths, which have consistently surpassed the national average. ${ }^{4}$ In 2009, Alberta ranked fourth in Canada for both the highest rate of impaired driving deaths per capita and the highest percentage of total crash deaths from impaired driving. ${ }^{5}$

In light of these alarming losses, it is perhaps surprising that Albertans who drive impaired are in large part shielded from civil liability through the province's mandatory automobile insurance regime. Under the current system, automobile insurers in Alberta are required to indemnify an insured up to policy limits for injury or property damage to third parties for which the insured is liable, regardless of whether such liability is incurred as a result of the insured's impaired driving. Prior to 1 June 1982, at least a portion of these payments were recoverable from the insured; relying on the "rights of creditors" provision of the Insurance Act, ${ }^{6}$ insurers could demand reimbursement for third party liability payments if the insured driver caused the loss while "under the influence of intoxicating liquor or drugs." ${ }^{7}$ However, with the passage of the Insurance Amendment Act of 1981, the statutory condition prohibiting impaired driving was removed, and with it, the right of insurers to recover these sums. ${ }^{8}$ The result has been called "a hard, sad reality for insurers" who now shoulder the cost of civil liability for impaired driving without recourse. ${ }^{9}$

The statutory ability of automobile insurers in Alberta to recover third party liability payments from their own insured can be conceptualized as a form of subrogation. A fundamental concept of insurance law, subrogation is the principle under which an insurer, having compensated an insured under a contract of insurance, becomes entitled to bring an action in the name of the insured against the wrongdoer to recover some or all of its payments. ${ }^{10}$ In other words, the insurer gains the right to "step into the shoes" of the insured and pursue the party legally responsible for the loss. ${ }^{11}$ Strictly speaking, an insurer's ability to recover payments from its own insured does not satisfy this definition; through injuries and fatalities in the year 1999 were subtracted from the totals in Table 4).

Pitel \& Soloman, supra note 1 at 3; Robert Soloman et al, "Mapping Our Progress to Safer Roads: The 2012 Provincial and Territorial Legislative Review" (31 March 2012), online: MADD Canada <http:// www.madd.ca/media/docs/MADD_Canada_2012_Provincial_and_Territorial_Legislative_ Review_ FINAL.pdf $>$ at 28.

Soloman et al, ibid at 27-28.

Ibid at 27.

RSA 1980, c I-5, s 320 [Insurance Act, 1980].

Ibid, s 299, Statutory Condition 2.

SA 1981, c 49.

Brian A Vail, "Vehicle Insurance Issues and Impaired Driving” (2009), online: 33:3 LawNow <http:// archive.lawnow.org/d/sites/default/files/SR3333.pdf> at 2. Several papers circulated by MADD Canada incorrectly state that automobile insurers in Alberta retain the right to sue their insureds to recover payments made to third parties following impaired driving collisions. As this article details, this right was eliminated by the Insurance Amendment Act, SA 1981, c 49 [Insurance Amendment Act, 1981] and remains unavailable to insurers today, contra MADD Canada, Automobile Insurance and Impaired Driving Across Canada: Executive Summary, online: MADD Canada Research Library <http://www. madd.ca/english/research/insurance_canada.pdf > at 11; Robert Solomon et al, “Automobile Insurance, Impaired Driving and Victim Compensation Across Canada" (2005) 12 MVR (5th) 22; MADD Canada, "Automobile Insurance, Impaired Driving, and You: A Look at Alberta’s Automobile Insurance Laws" (December 2004), online: MADD Canada Research Library <http://www.madd.ca/english/research/ Alberta.pdf $>$.

10 Barbara Billingsley, "Somersall, Subrogation and the Supreme Court: How the Top Court's Ruling in Somersall v. Friedman Undermines Insurance Law Theory and Practice” (2003) 40:4 Alta L Rev 917. See also: Black's Law Dictionary, 9th ed, sub verbo "subrogation." Billingsley, ibid at 917. 
subrogation, the insurer acquires only the rights possessed by the insured, and clearly, the insured would not sue his or herself. ${ }^{12}$ Despite this technical inaccuracy, subrogation is conveniently used to describe the "insurer v. insured" cause of action. In this context, the prior ability of automobile insurers to recover payments made to victims of impaired driving from their own at-fault insureds has been described as an exception to the rule that an insurer cannot subrogate against its own insured. ${ }^{13}$

With the 1982 amendment removing this "subrogation" right in the context of impaired driving, it is reasonable to evaluate the amendment by considering its impact on the public policy objectives ordinarily associated with subrogation. In the context of liability coverage, subrogation serves three main purposes. First, the victim receives full and upfront compensation from the insurer without having to sue the wrongdoer. ${ }^{14}$ By this same principle, the subrogation prevents double-recovery by the insured for the same loss. ${ }^{15}$ Second, subrogation shifts the financial burden of a loss to the wrongdoer, preventing him or her from evading responsibility on the fortuitous existence of insurance coverage. ${ }^{16}$ Finally, subrogation provides the insurer with a means of recovering funds they would not otherwise have been required to pay but for the acts of the wrongdoer. This, in turn, removes the wrongful act from the risk shouldered by the other insureds in an insurance pool, which may reduce overall rates. ${ }^{17} \mathrm{On}$ its face, the elimination of the automobile insurer's right to recover insurance proceeds from its insured who was driving while impaired seems to contradict these aims. However, a close examination of the practical difficulties and policy concerns associated with this issue reveals that, compared to the previous approach, Alberta's current system of third party liability coverage better serves the objectives of subrogation.

\section{Parameters of THis Discussion}

This article will comment only on the automobile insurance treatment of impaired drivers in Alberta. ${ }^{18}$ Specifically, the focus will be the province's mandatory automobile liability insurance as set out in section A of the Alberta Standard Automobile Policy, S.P.F. No. 1. ${ }^{19}$ This is the government approved form of an owner's policy for automobile insurance in

12 SR Derham, Subrogation in Insurance Law (Sydney: The Law Book Company, 1985) at 75.

13 Rita R Tripathy \& Lisa M Monteith, "Breaches of the Automobile Insurance Contract" (November 2005), online: BD\&P Insurance Newsletter <http://www.bdplaw.com/titanweb/bdp/BDPWEBSITE. NSF/AllDoc/E0092F793919D91B87256F87006FC597?OpenDocument> at 2.

14 Billingsley, supra note 10 at 917.

15 Ibid.

16 Ibid. See also Craig Brown \& Thomas Donnelly, Insurance Law in Canada, loose-leaf (consulted on 1 December 2012), (Toronto: Thomson Carswell, 2002) ch 13 at 29.

17 However, in Somersall v Friedman, 2002 SCC 59, [2002] 3 SCR 109 at para 71 [Somersall], the majority of the Supreme Court of Canada casts doubt on the economic value of subrogation rights, referring to them as "rarely very valuable at all." Further discussion can be found below.

18 According to Craig Brown and Julio Menezes, by the early 1990s, the majority of the provinces had similarly removed conditions prohibiting driving while incapacitated by alcohol or drugs (Craig Brown \& Julio Menezes, Insurance Law in Canada, 2d ed (Scarborough: Carswell, 1991) at 171). Today, only Saskatchewan, British Columbia, and Manitoba have statutory conditions or regulations prohibiting the insured from operating an automobile while impaired by liquor or drugs to such an extent as to be incapable of proper control of the automobile. See generally CED Insurance (West) X.3.(e) §654). See also The Saskatchewan Insurance Act, RSS 1978, c S-26, s 192, Statutory Condition 2(1)(a); Insurance (Vehicle) Regulation, BC Reg 447/1983, s 55(8)(a); Automobile Insurance Coverage Regulation, Man Reg 290/88R, s 56(1)(a).

19 Alberta Standard Automobile Policy SPF No 1 (1 July 2008), online: Alberta Finance <http://www. finance.alberta.ca/publications/insurance/standard_automobile_policy_2012.pdf> [SPF No 1]. 
Alberta. ${ }^{20}$ S.P.F. No. 1 is comprised of three sections which function as separate contracts of insurance. ${ }^{21}$ Mandatory section B coverage provides insureds with various no-fault accident benefits in the event they sustain an injury arising from the use or operation of an automobile. ${ }^{22}$ Insureds also have the option of securing section C coverage to protect against property damage to the automobile named in the policy. ${ }^{23}$ In an impaired driving accident, amounts paid out under these sections are often greatly exceeded by payments made to third parties under section A. ${ }^{24}$ Mandatory section A coverage requires the insurer to indemnify the insured against liability imposed by third parties due to property damage, injury, or death as a result of the insured's driving. ${ }^{25}$ Section $\mathrm{A}$, therefore, operates as the principal victim compensation scheme in impaired driving accidents and forms the subject of this discussion. A comparative analysis of section A coverage before and after the 1982 amendment will be undertaken in the context of Alberta's fault-based delivery of third party accident compensation. ${ }^{26}$ Finally, for simplicity's sake, the ability of insurers to recover third party payments from their own insureds in impaired driving scenarios will be referred to as "subrogation."

\section{The First ObJective Of Subrogation: ENSURING COMPENSATION FOR VICTIMS}

Crucial to the delivery of section A coverage is the rights of creditors provision of the Insurance Act. ${ }^{27}$ Currently, this provision provides third party accident victims with a direct right of action against an automobile liability insurer. ${ }^{28}$ To exercise this right, third parties must obtain a final judgment against the insured. ${ }^{29}$ This judgment can then be relied on to claim payment directly from the insurer. The rights of creditors provision thus relieves third parties of the burden of proving liability as against the insurer itself. ${ }^{30}$ A third party's right of action against the insurer exists independently of the insured's right to claim under the policy. The section prioritizes victim compensation, as illustrated by the fact that an insurer may be required to "[make] a payment under a policy to a third party in a situation where a claim made by the insured would be denied." 31

The insurer's defences to the third party claim are extremely limited. Payment may be denied on the basis that, at the time of the accident, the policy did not exist, did not cover the driver, did not cover the type of loss claimed, or was expired..$^{32}$ Provided there was a valid

Specifically, the form receives the approval of the Superintendent of Insurance and is published for use by automobile insurers throughout Alberta (Insurance Act, RSA 2000, c I-3, s 551 [Insurance Act, 2000]). See generally Brown \& Donnelly, supra note 16, ch 17 at 5.

$21 \quad$ Vail, supra note 8 at 1.

22 SPF No 1, supra note 19 at 2. The definition of an "insured" under sections A, B, and C differs substantially. For a summary, see Vail, ibid at 4.

SPF No 1, supra note 19 at 10.

Vail, supra note 8 at 3.

SPF No 1 , supra note 19 at 1.

The merits of this system will not be evaluated in this article. For a recent comparative review of this issue see Mark Kelly, Anne Kleffner \& Maureen Tomlinson, "First-Party Versus Third-Party Compensation for Automobile Accidents: Evidence from Canada” (2010) 13:1 Risk Management and Insurance Review 21.

Insurance Act, 2000, supra note 20, s 579.

Brown \& Donnelly, supra note 16 , ch 17 at 84.

Insurance Act, 2000, supra note 20, s 579(1).

Brown \& Donnelly, supra note 16 , ch 17 at 84.

Tripathy \& Monteith, supra note 13 at 2.

Ibid. 
policy in place at the time of the accident, the insurer will generally be bound to cover a third party loss, at least up to the statutory minimum of $\$ 200,000 .{ }^{33}$ Pursuant to section 579(4), the insurer is not entitled to deny third party claims on the basis that the insured violated the Insurance Act or breached a term of the policy. ${ }^{34}$ Nor, by virtue of section 579(5), is it a defence that the insured's conduct rendered the policy void $a b$ initio. ${ }^{35}$ The otherwise harsh effect of these restrictions is tempered by section 579(11). Notwithstanding subsection (4), section 579(11) allows the insurer to avail itself of any defence it would be entitled to use against the insured for the portion of the third party claim exceeding $\$ 200,000 .{ }^{36}$ By virtue of this subsection, the insurer can rely on the insured's fraud, misrepresentation, or failure to report a change material to the risk. However, section 579(11) expressly precludes an insurer from defending a third party claim, even in excess of \$200,000, on the basis that the insured breached Statutory Condition 2, which is as follows:

\section{Prohibited Use by Insured}

2(1) The insured must not drive or operate the automobile

(a) unless the insured is for the time being either authorized by law or qualified to drive or operate the automobile,

(b) while the insured's licence to drive or operate an automobile is suspended or while the insured's right to obtain a licence is suspended or while the insured is prohibited under order of any court from driving or operating an automobile,

(c) while the insured is under the age of 16 years or under any other age prescribed by the law of the province in which the insured resides at the time the contract is made as being the minimum age at which a licence or permit to drive an automobile may be issued to the insured,

(d) for any illicit or prohibited trade or transportation, or

(e) in any race or speed test. ${ }^{37}$

As discussed below, the omission of impaired driving from this list has significant consequences for current automobile insurers in Alberta.

The rights of creditors provision contemplates the possibility of a third cause of action in connection with a section A claim. ${ }^{38}$ In addition to the "tort action," in which the third party obtains a judgment against the insured, and the "judgment creditor action," in which the third party claims directly against the insurer, the insurer may bring a third action against its own insured for reimbursement of money paid to the judgment creditor. However, this action is only available in narrowly defined circumstances. Specifically, if the insurer is prevented by

The compulsory minimum for third party liability coverage as set out in the Insurance Act, 2000, supra note 20 , s 571 .

Tripathy \& Monteith, supra note 13 at 2.

See Brown \& Donnelly, supra note 16, ch 17 at 87.

Insurance Act, 2000, supra note 20, s 571.

Ibid, s 556(1), Statutory Condition 2.

Ibid, s 579(13). 
section 579 from raising an insured's breach as a defence in the third party action, section 579(13) allows the insurer to seek recovery from the insured. ${ }^{39}$ In other words, section 579(13) allows the insurer to subrogate against its own insured where it has been required to satisfy a third party claim that it would not otherwise have been required to pay but for the operation of section $579 .^{40}$

The current system of section A coverage for impaired drivers in Alberta is the result of two significant legislative amendments. The first of these, the Insurance Amendment Act, 1975, added the words "other than a defence arising out of a breach of statutory condition 2 ” to the equivalent of the current section $579(11) .{ }^{41}$ Critically, Statutory Condition 2 at that time included the following:

Prohibited Use by Insured

2(1) The insured must not drive or operate the automobile,

(a) while under the influence of intoxicating liquor or drugs to such an extent as to be for the time being incapable of the proper control of the automobile. ${ }^{42}$

The result of this slight change in wording was a substantial increase in the compensation available to third party victims of impaired driving. Despite the insured's breach of Statutory Condition 2, the insurer became liable to third party claims up to the full limits of the policy. ${ }^{43}$ However, it remained possible for the insurer to recover these payments; prevented by section 579(11) from raising the insured's impaired driving as a defence against the third party, the equivalent of section 579(13) afforded the insurer a right of subrogation against the insured:

\section{Rights of Creditors}

306(13) The insured shall reimburse the insurer upon demand in the amount that the insurer has paid by reason of this section that it would not otherwise be liable to pay. ${ }^{44}$

The purpose of the Insurance Amendment Act, 1975 on victim compensation was explicitly referenced during the second reading of the bill:

The intent of the amendment is to increase the third party liability coverage to innocent third parties, other than gratuitous passengers, when there is a breach of statutory condition 2. At present an innocent third party can only recover, under the insurance contract, up to the minimum compulsory insurance of $\$ 50,000$. But

Brown \& Donnelly, supra note 16 , ch 17 at 89.

Tripathy \& Monteith, supra note 13 at 2.

SA 1975, c 59, s 306(11) [Insurance Amendment Act, 1975].

Insurance Act, supra note 6, s 299(2), Statutory Condition 2. Section 299(2) also contained a corresponding statutory condition prohibiting the insured from permitting, suffering, allowing or conniving at the use of the automobile "by any person under the influence of intoxicating liquor or drugs to such an extent as to be for the time being incapable of the proper control of the automobile.” While prohibited use by others is beyond the scope of this article, it is important to note that this section was also removed by the 1982 amendment.

The 1975 amendment is not mentioned by Vail, supra note 8.

Insurance Act, RSA 1970, c 187. 
if the amendment goes through, he will now be able to sue and recover up to the limits of the coverage included in an insurance contract. The insurance company, of course, will still be in a position to subrogate itself against the insured in such instances. The amendment has been recommended by the Insurance Bureau of Canada and I might say this amendment will lead us down the road to eventually eliminating statutory condition $2 .^{45}$

As predicted, the statutory condition prohibiting impaired driving was removed seven years later by section 5 of the Insurance Amendment Act, $1981 .{ }^{46}$ Since 1 June 1982, insurers have not been able to subrogate against their own insureds for section A payments made as a result of the insured's impaired driving. On its face, this change does not appear to impact victim compensation. Consider, for example, a third party with a claim of $\$ 250,000$ against an impaired driver, who has $\$ 500,000$ in third party liability coverage and $\$ 50,000$ in assets. Prior to the 1982 amendment, the insurer would have been required to pay the entirety of the victim's claim (because it fell within the limits of the policy) but could then demand reimbursement from its insured. If, as in this example, the driver had insufficient assets to satisfy the claim, the shortfall was borne by the insurer and the victim remained fully compensated. Following the 1982 amendment, while the insurer became unable to access the assets of the insured, the victim would have continued to receive full, upfront compensation.

The intention behind this change, however, suggests that victims encountered practical difficulties under the prior system of subrogation. ${ }^{47}$ While there is no objective or empirical evidence regarding the delivery of section A payments, the comments of the legislature raise logical concerns that the amendment aimed to rectify. As Brian Vail observes, "the government carried out these amendments because it was deluged with complaints about how the pre-amendment system worked. The system was widely perceived to be unfair." ${ }^{48}$ The legislature noted that insurers would frequently insist on obtaining a non-waiver agreement from their insured before they would recognize the third party claim. ${ }^{49}$ Not surprisingly, few insureds would agree to sign a non-waiver that would preserve the insurer's right to subrogate against them. Consequently, even where the circumstances of the accident left no question as to who was at fault, the third party victim would be forced to litigate and obtain a judgment against the insured before the insurer would agree to pay its claim. ${ }^{50}$ The legislature suggested that the insurer's right to subrogation was precluding settlements with victims at the adjustor level and necessitating the use of court processes. ${ }^{51}$ This process was cited as problematic for two reasons. First, forcing third parties to incur legal expenses effectively reduced compensation intended for personal injury and property damage. Second, the inevitable delays of litigation meant that adjudication of claims could span years, exacerbating expenses and withholding payment from victims in the post-accident period. ${ }^{52}$ On the basis of these cited difficulties, the legislature concluded that, in practice, subrogation

Supra note 41; Alberta, Legislative Assembly, Hansard, 18th Leg, 1st Sess, (17 November 1975) at 1133 (Graham Harle) [emphasis added].

Supra note 9 , s 5.

Alberta, Legislative Assembly, Hansard, 19th Leg, 3rd Sess, (30 October 1981) at 1357 (Julian Koziak) [Hansard 1981].

Vail, supra note 8 at 2.

Hansard 1981, supra note 47.

Ibid.

Ibid.

Ibid. 
was "penalizing the innocent third party." ${ }^{\text {"I }}$ If this is an accurate depiction of the province's experience under the pre-amendment system, then Alberta's current approach to section A coverage of impaired drivers is more consistent with subrogation's objective of ensuring victim compensation.

\section{THE SECOND OBJECTIVE OF SUBROGATION: SHIFTING THE LOSS TO THE WRONGDOER}

Holding wrongdoers financially responsible is an attractive argument for Alberta's prior approach to section A liability coverage. By allowing an insurer to recover payments made to innocent third parties, subrogation required insureds to be financially liable for their tortious behaviour and thereby denounced impaired driving. Given the staggering rate of injury and fatality associated with impaired driving, it may seem morally objectionable that offending individuals are now permitted to contract out of responsibility for the losses they cause innocent members of the public. ${ }^{54}$ The dialogue that emerges is, "whether an insured 'like that' who does 'those things' should 'deserve' insurance protection." ${ }^{55}$ Concerns about the appropriate condemnation of impaired driving are reinforced by the related view that liability coverage rewards rather than deters the behaviour. ${ }^{56}$ Third party liability coverage intact, any corrective or deterrent effects of a civil judgment are not felt by impaired drivers, at least to the extent that a claim falls within their insurance policy limits. ${ }^{57}$ However, these alleged shortcomings of Alberta's current approach must be measured against the practical realities of subrogation in impaired driving scenarios.

Insulating offending drivers from tort liability contradicts the criminal and administrative treatment of impaired driving. Despite toughening administrative penalties for drivers caught with blood alcohol concentrations below the legal limit of .08 percent but above .05 percent, the province continues to operate an automobile insurance scheme that prevents these individuals from being held personally liable to their victims. ${ }^{58}$ The federal attitude towards impaired driving, as reflected in the Criminal Code ${ }^{59}$ appears similarly undermined because mandatory third party liability coverage renders impaired drivers "fully insurable for the civil consequences of their criminal behaviour." ${ }^{\circ 0}$ In the United States, it has been suggested that automobile insurance should operate to compliment the criminal law in denouncing impaired driving. ${ }^{61}$ Indeed, consistent insurance, criminal, and regulatory treatment of the problem could render more consistent and predictable consequences for offenders. Proponents of

$53 \quad$ Ibid

Avi Perry, "Restructuring Insurance Coverage for Drunk Drivers” (2010) 4:2 Harvard Law \& Policy Review 427 at 428; Derham, supra note 12 at 154.

55 Tom Baker, "Constructing the Insurance Relationship: Sales Stories, Claim Stories, and Insurance Contract Damages” (1993) 72:6 Tex L Rev 1395 at 1412 cited in Erik S Knutsen, "Fortuity Clauses in Liability Insurance: Solving Coverage Dilemmas for Intentional and Criminal Conduct” (2011) 37 Queen's LJ 73 at 105.

Knutsen, ibid at 105.

Perry, supra note 54 at 431.

Alberta Government, News Release, “Impaired Driving Limits Haven’t Changed. The Penalties Have” (27 August 2012) online: Government of Alberta <http://alberta.ca/NewsFrame.cfm?ReleaseID=/ acn/201208/3287668A5AE15-C7E0-07CD-36EF38749F52D001.html>.

RSC 1985, c C-46.

Perry, supra note 54 at 431.

Ibid at 433. 
subrogation might also suggest that subrogation bridged this policy gap and reinforced a legislative commitment to eradicating impaired driving.

Without the ability of insurers to subrogate for third party liability payments, the present insurance ramifications of impaired driving in Alberta are comparatively minor. Following an accident or conviction, the offending insured will likely experience an increase in automobile insurance premiums. The magnitude of this increase is determined by complex formulae detailed in the Automobile Insurance Premiums Regulation. ${ }^{62}$ Under schedule 1, section 5(3), a driver's "base premium" 63 is multiplied by a percentage that corresponds to his or her "step" on the grid set out in schedule 2, which ranges from 50 percent to 338 percent. The appropriate grid step decreases by one for each year of driving experience. However, one at-fault claim in the preceding six year period increases a driver's placement on the grid by five steps. ${ }^{64}$ In addition, surcharges are added for at-fault accidents and driving convictions in the past three years. ${ }^{65}$ For example, a single conviction under the Criminal Code for impaired driving in the last four years results in a 300 percent surcharge being added to the driver's automobile insurance premiums. ${ }^{66}$

Impaired drivers may also be precluded from claiming certain section B benefits and any section C benefits. Since 1971, drivers convicted of driving with a blood alcohol concentration exceeding .08 percent or while their ability to do so is impaired by alcohol or drugs, have been denied total disability benefits under their mandatory section B automobile insurance ${ }^{67}$ The exclusion of section $\mathrm{C}$ coverage for impaired drivers is slightly more recent. The changes were introduced concurrently with the critical 1982 amendment. ${ }^{68}$ By removing the ability of the impaired insured to collect for damages to his or her own vehicle, the legislature intended to temper concerns that the overall impact of the legislation would be to "make it easier on the drunk driver." ${ }^{69}$ However, it is also important to note that section C coverage remains optional. ${ }^{70}$ Therefore, the insured who chooses not to expend premiums protecting his or her vehicle, and subsequently damages it while driving impaired, does not suffer a "loss" of these benefits as the legislature contemplated. Similarly, if this same insured walks away from an accident unharmed and without the need for total temporary disability benefits under section $B$, the sole insurance effect is an increase in future premiums. Such scenarios can be used to bolster the argument that the current insurance consequences of impaired driving are insufficient and fail to effectively shift the loss to the wrongdoer. Yet exposing impaired drivers to the full impact of their civil liability through subrogation may similarly fail to accomplish this objective.

\footnotetext{
$62 \quad$ Alta Reg 124/2004.

63 Ibid, schedule 3, s 2 (Base premium is determined according to where the policyholder resides and the amount of coverage they choose).

Ibid, schedule 1, s 5(3).

Ibid, schedule 4 .

Ibid, schedule 4, table 1.

Automobile Accident Insurance Benefit Regulation, Alta Reg 305/1971, s 4. For the current version, see Automobile Accident Insurance Benefit Regulations, Alta Reg 352/1972, Special Provision 2(b)(i). The Superintendent of Insurance approved a Certificate of Automobile Insurance and Standard Automobile Policy effective 1 June 1982 (see Proclamation, 30 October 1982, (1982) A Gaz I, 3312, 3324-25). For the current version, see SPF No 1, supra note 19. 
The operation of subrogation in impaired driving scenarios cannot ensure that the loss is confined to the wrongdoer alone. Rather, in the name of publicly condemning impaired driving, subrogation actually has the potential to create more victims. Consider the situation contemplated by the legislature prior to passing the Insurance Amendment Act, 1981:

\footnotetext{
You would have the situation of an individual who has once made a mistake, has been responsible throughout his life in all other respects - provided for his family, dependants, and children a house, a good standard of living, and a good education — as a result of this one error.... He may have been found guilty in court. He may have been sentenced in court. But in addition, a further sentence can be imposed that can go to the limits of the policy that insured had, if it were \$1 million, when combined with the amount the insurer had to pay out under the circumstances. That may mean that subject to the exemptions allowable under The Exemptions Act, which aren't that substantial, the insured may lose his home, any assets he may have, and his ability to respond to the needs of the family. Who suffers? The innocent family of the insured. We want to correct that. ${ }^{71}$
}

As the legislature pointed out, shifting the burden of a civil judgment from an insurer to an insured has the potential to dramatically and negatively impact the lives of the insured's dependents. Like the victim of an impaired driver, the insured's spouse and children have done nothing wrong. Yet, depending on the value of the third party claim, they could be left with only the essentials of life. Exemptions to civil judgments under the modern Civil Enforcement Act and associated regulations remain meager. ${ }^{72}$ If subrogation remained a permitted course of action today, the family of an impaired driver with insufficient assets to reimburse an insurer would only be entitled to keep the following: sufficient food for the next 12 months, clothing up to value of $\$ 4,000$, household furnishings up to a value of $\$ 4,000$, one motor vehicle up to a value of $\$ 5,000$, necessary medical and dental aids, and a principal residence up to a value of $\$ 40,000 .^{73}$ To be sure, the traditional home life contemplated by the legislature is not the case for all insureds who commit impaired driving offences. There will undoubtedly be impaired drivers without obligations to dependents or those with sufficient assets to continue to live well even after reimbursing an insurer for a third party claim. The current system may fail to accomplish the goals of subrogation in these cases. However, it succeeds in protecting blameless families from the threat of financially crippling civil judgments. Ultimately, Alberta's current system sacrifices the indiscriminate appearance of justice in favour of sheltering more innocent parties from the effects of impaired driving.

Not only does subrogation risk punishing families of insureds, but it does so with no assurances of deterring impaired driving in the first place. Though he advocates for the restructuring of third party liability automobile insurance to allow for subrogation, Avi Perry concedes that "the deterrence argument seems somewhat of an awkward fit" in the context of impaired driving. ${ }^{74}$ As he notes, it is difficult to argue that the availability of insurance encourages or even factors into an individual's decision to drive while impaired. ${ }^{75}$ This is because impaired driving accidents, while punishable under the criminal law, remain

Supra note 9; Hansard 1981, supra note 47 at 1358.

RSA 2000, c C-15, s 88.

Civil Enforcement Regulations, Alta Reg 276/1995, s 37(1).

Perry, supra note 54 at 431.

Ibid at 431; Derham accepts that the threat of civil liability may deter some intentional tortfeasors, but questions its possible impact on negligent or reckless acts (see Derham, supra note 12 at 154 ). 
accidents; ${ }^{76}$ without the subjective intent to cause a loss to third parties, it is unrealistic to suggest that impaired insureds weigh the insurance consequences before driving. ${ }^{77}$

The deterrence argument is also refuted by the availability of serious regulatory and criminal penalties for impaired driving. Under the recent and highly publicized amendments to the Alberta Traffic Safety Act, drivers caught with blood alcohol concentrations exceeding .05 percent now have their licences suspended and vehicles seized for a minimum of three days. ${ }^{78}$ Still, the primary mechanism for punishing impaired driving remains the criminal law. ${ }^{79}$ Under the Criminal Code, it is a crime to operate a motor vehicle with a blood alcohol concentration in excess of .08 percent or while one's ability to do so is otherwise impaired by alcohol or drugs. ${ }^{80}$ Criminal charges may also flow from the refusal or failure to comply with a police officer's demand for breath, blood, urine, or saliva samples. ${ }^{81}$ The penalties for these offences are severe: in addition to a mandatory driving prohibition, ${ }^{82}$ at minimum, offenders receive a $\$ 1,000$ fine for a first offence, a jail term of 30 days for a second offence, and a jail term of 120 days for each subsequent offence. ${ }^{83}$ Impaired drivers convicted of causing bodily harm are liable to imprisonment for up to ten years and those convicted of causing death are liable for a life sentence. ${ }^{84}$ While they may not be aware of the specifics, it is safe to say that most Albertans appreciate that impaired driving is a crime with serious penalties.

The severity of the existing consequences of impaired driving make it unlikely that the threat of a civil judgment would have a significant deterrent effect. If individuals are willing to risk imprisonment, it is doubtful that the comparatively long-term financial consequences of reimbursing their insurer for a third party claim would affect their behaviour. ${ }^{85}$ In other words, "[e]ven a short stay in a jail cell would surely loom larger in the imagination than an uninsured tort liability." ${ }^{\text {" }}$ Even graver than the criminal law consequences, impaired driving carries the very real threat of injury or death to the driver. ${ }^{87}$ From a logical viewpoint, there could not be a more powerful deterrent. Yet, it is clear that this threat has not been sufficient to prevent impaired driving. This is because impaired driving is not the rational product of a cost-benefit analysis, and consequently, the financial impact of subrogation remains unlikely to tip the scales. ${ }^{88}$

Weighing the above considerations, it becomes clear that, despite initial appearances, Alberta's current automobile insurance system is consistent with the objective of shifting losses to wrongdoers. This conclusion is the result of realizing, as the legislature did, that

See Knutsen, supra note 55 at 80-81.

Stephen G Gilles, “The Judgment-Proof Society” (2006) 63:2 Wash \& Lee L Rev 603 at 675.

RSA 2000, c T-6, ss 88-89.

Perry, supra note 54 at 433.

Supra note 59, s 253.

Ibid, s 254(5).

Ibid, s 259.

Ibid, s 255(1).

Ibid, ss 255(2), 255(2.1), 255(2.2) (punishment for offences causing bodily harm). Ibid, ss 255(3), 255(3.1), 255(3.2) (punishment for offences causing death).

85 Tom Baker, "Liability Insurance at the Tort-Crime Boundary" in David M Engel \& Michael McCann, eds, Fault Lines: Tort Law as Cultural Practice (Palo Alto: Stanford University Press, 2009), online: <https://www.law.upenn.edu/cf/faculty/thbaker> at 8 [Baker, Tort-Crime”].

Ibid.

Gilles, supra note 77 at 675 .

Baker, “Tort-Crime,” supra note 85. 
subrogation in practice may not serve its theoretical justification of forcing impaired drivers to bear the cost of their liability to third parties. Subrogation threatens the livelihood of an insured's dependents, potentially forcing them to shoulder the burden of someone else's tortious behaviour. Furthermore, requiring impaired drivers to internalize the costs of the liability they incur is unlikely to have a deterrent effect; when considered alongside the more tangible consequences of jail time, injury, or death, the threat of a civil judgment seems unlikely to sway would-be impaired drivers. However, these considerations must be qualified as pertaining only to the current state of civil actions against impaired drivers in Alberta, which, to this day, have not resulted in an award of punitive damages. Such an outcome was recently approved by the second highest judicial authority in Canada, the Ontario Court of Appeal. Should Alberta courts follow suit, the province's approach to automobile liability insurance should be adjusted.

In McIntyre v. Grigg, the Ontario Court of Appeal confirmed the first and only Canadian award of punitive damages against an impaired driver. ${ }^{89}$ At the time she was hit by the defendant's vehicle, the plaintiff, Andrea McIntyre, was a first-year university student and athlete. ${ }^{90}$ As a result of the accident, she suffered a serious closed-head injury, a fractured femur, and various other soft tissue and orthopeadic injuries. ${ }^{91}$ The plaintiff continued to suffer physical and psychological effects six years after the accident, unable to resume athletics and having attempted suicide twice. ${ }^{92}$ The defendant, Andrew Grigg, had been drinking at a university pub before driving home. A breathalyzer test was administered after the accident. However, the police failed to inform him of his right to counsel and the results were ultimately deemed inadmissible. ${ }^{93}$ As a result, he was charged with careless driving and received a fine of only $\$ 500 .{ }^{94} \mathrm{~A}$ civil trial commenced, in which the jury ultimately granted an award of \$100,000 in punitive damages. Writing for the majority of the Court of Appeal, Chief Justice McMurtry concluded that:

By making the deliberate choice to drink excessively and then drive, Andrew Grigg's misconduct was more than mere negligence. It demonstrated a conscious and reckless disregard for the lives and safety of others. There was evidence he was two to three times over the legal limit for alcohol consumption and was speeding and driving recklessly. In our view, this was sufficient evidence for the jury to find that an award of punitive damages was warranted. ${ }^{95}$

The aims of such an award would be frustrated under Alberta's current approach to third party liability insurance of impaired drivers. Punitive damages, as the majority recognized in McIntyre, are intended to punish, deter, and denunciate a defendant's conduct. ${ }^{96}$ Without addressing the appropriateness of punitive damages in this case, or in negligence cases

(2006), 83 OR (3d) 161, 274 DLR (4th) 28 (ONCA) [McIntyre].

Ibid at para 12.

Ibid at para 13 .

Ibid at paras 14-16.

Rita R Tripathy, “Will Punitive Damages Against Impaired Drivers Punish the Insurance Industry?” The Lawyers Weekly 26:33 (12 January 2007) (QL).

McIntyre, supra note 89 at para 11.

Ibid at para 57.

Ibid at para 59; Whiten v Pilot Insurance Co, 2002 SCC 18, [2002] 1 SCR 595 at paras 43, 68 [Whiten]. 
generally, ${ }^{97}$ it is clear that these purposes are not met when an insurer is responsible for paying the award. Breaking from the Canadian judicial norm in his dissent, Justice Blair explicitly considered the defendant's insurance coverage, ${ }^{98}$ noting that:

\begin{abstract}
Mr. Grigg is required by law in Ontario to be insured. Although the details of his insurance are not before the court, the Standard Automobile Owner's Policy provides that where the insured is legally responsible for the bodily injury to, or death, of others, or for damage to the property of others, as a result of owning, using or operating the insured automobile, the insurer "will make any payment [on the insured's behalf] that the law requires, up to the limits of the policy." Nothing in the Standard Policy terms exclude punitive damages from this provision, and nothing negatives coverage vis-à-vis third parties as a result of intoxication. Thus, it is unlikely that Mr. Grigg — or other impaired drivers in similar situations — will have to pay the punitive damages awarded (subject to policy limits).
\end{abstract}

What, then, is accomplished in the way of punishment or deterrence by such an award? An award of punitive damages in these circumstances does little to advance the objectives of punitive damages, in my opinion. ${ }^{99}$

The Alberta Standard Automobile Policy, S.P.F. No.1, like that of Ontario, does not appear to preclude coverage for impaired driving or for punitive damages. ${ }^{100}$ A similar award under the current system would not be felt personally by the insured wrongdoer and, thus, could not achieve its intended punitive effect. ${ }^{101}$

If the risk of punitive damages becomes significant in Alberta, the current third party liability scheme should be amended in order to preserve the second objective of subrogation. This could be accomplished through an exclusion under section A. ${ }^{102}$ As such awards are not intended to be compensatory, insurers should not be required to front the initial costs of punitive damages and potentially recover from their insured through subrogation ${ }^{103}$ Rather, it is acceptable if an insured is insolvent and unable to satisfy the punitive damages portion of a civil judgment. Concerns over victimizing the family of an impaired driver are similarly mitigated in this context. Punitive damages are governed by the principle of proportionality, which requires that triers of fact take into account compensatory damages and any other punishment related to the same misconduct in determining the appropriate quantum. ${ }^{104}$ Furthermore, appellate courts retain the power to intervene if an award of punitive damages "exceeds the outer boundaries of a rational and measured response to the facts of the case."105 It would seem unlikely, therefore, that the financial effect an uninsured award of punitive damages would raise the same concerns as requiring an insured to reimburse its insurer for the entire judgment through subrogation. Only time will tell if such an exclusion is necessary, as McIntyre remains a singular example in Canadian jurisprudence. Yet, as one commentator

See Lori Leung, “An Evaluation of the Award of Punitive Damages in McIntyre v. Grigg” (2008) 34 Advoc Q 376; Alf Kwinter, "Decisions Range All Over the Map on Punitive Awards" The Lawyers Weekly 28:8 (20 June 2008) (QL). More generally, see James A Niquet, "Insurance Against Punitive Damages in Drunk Driving Cases” (1986) 69 Marq L Review 306. Leung, ibid at 384.

McIntyre, supra note 89 at paras 131-32 [emphasis omitted].

SPF No 1, supra note 19.

Leung, supra note 97 at 385.

For a brief discussion on how this is done in general liability insurance contracts, see Baker "TortCrime," supra note 85 at 6-7.

Whiten, supra note 96 at para 36

Ibid at para 74.

Ibid at para 76 . 
observed, the Ontario Court of Appeal has opened the door to similar awards in cases of impaired driving across the country. ${ }^{106}$ If Alberta courts demonstrate a willingness to award punitive damages in the future, preserving the objective of wrongdoer responsibility will require the legislature to address third party liability coverage accordingly.

\section{THE THIRD OBJECTIVE OF SUbROgATION: REDUCING THE COST OF INSURANCE}

The comparative success of Alberta's current approach to section A coverage must also be evaluated in monetary terms. Prior to the 1982 amendment, subrogation operated to allow insurers to recoup at least a portion of their third party liability payments - payments that would not have been made but for the insured's impaired driving. Theoretically, these recoveries would factor into the insurer's calculation of premium rates, lowering the overall cost of insurance. ${ }^{107}$ The relevant inquiry, then, is whether the removal of the insurer's right to subrogate against their own impaired insured was economically advantageous for the Alberta automobile insurance industry. If the cost-saving justification for subrogation is accepted, then the removal of this mechanism should have produced a corresponding increase in automobile insurance premiums.

Underpinning the economic rationale for subrogation is a simple fairness argument: Why should the financial risk of impaired driving to the insurer be mitigated through increased premiums from law-abiding insureds? No longer included as a prohibited use under Statutory Condition 2, the civil liability of impaired drivers is now one of the risks assumed by automobile insurers in Alberta. Presumably, insurers have increased their reserves for losses accordingly. ${ }^{108}$ Yet, impaired driving remains criminal behaviour and certainly not one that all insureds will engage in. Closely connected to an objective of shifting the loss to the wrongdoer, there is understandable reluctance towards the inclusion of criminals in the automobile insurance pool. ${ }^{109}$ Without the right of the insurer to subrogate against an offending insured, innocent insureds pay, through their own monthly premiums, for the costs of impaired driving. ${ }^{110}$ Subrogation, at least in theory, confines the loss to the at-fault insured rather than spreading it across the price of insurance for all drivers.

To accurately assess Alberta's current approach, account must be taken of the fact that subrogation comes with its own costs. By definition, subrogation encourages litigation, which carries significant expenses for all involved. ${ }^{111}$ The potential economic impact of this process on third party accident victims was expressly contemplated by the legislature prior to passing the Insurance Amendment Act, 1981. The time and expense of securing a judgment against an impaired driver were deemed to reduce the intended benefit of an eventual section A payment by the insurer. ${ }^{112}$ The same concerns arise in the context of a subrogated action

Leung, supra note 97 at 376.

Derham, supra note 12 at 153; Billingsley, supra note 10 at 917.

Borrowing from the dissenting reasoning of Justice Blair in McIntyre, when insurers become exposed to increasing risk, they will inevitably increase their available funds through increased premiums, see McIntyre, supra note 89 at para 133.

Baker “Tort-Crime," supra note 85.

Ibid at 11.

Billingsley, supra note 10 at 927.

Hansard 1981, supra note 47 at 1357. 
by an insurer against its own insured. In addition to legal fees and delays, the handling of recoveries obtained through subrogation could result in higher administrative costs for insurers. ${ }^{113}$ In order for the economic rationale to be viable, recoveries must therefore be capable of offsetting the procedural expenses of subrogated actions and their collective effect on the insurance system as a whole. ${ }^{114}$ Unfortunately, there is no empirical evidence from which to evaluate the economics of subrogation by an insured against its own insured. Similarly, the magnitude of section A payments in the context of impaired driving cannot be estimated with any accuracy. In light of this evidentiary gap, the comments of the Supreme Court of Canada on the value of subrogation rights are useful for assessing Alberta's current system of third party liability coverage.

The Court's decision in Somersall v. Friedman raises many questions as to the necessity of subrogation as a doctrine of insurance law. ${ }^{115}$ The case concerned a settlement agreement between the insured and an underinsured tortfeasor. Specifically, the Court was asked to determine whether this agreement, which prevented the insurer from advancing a subrogated claim against the tortfeasor, justified the insurer's denial of underinsured motorist coverage to its insured. ${ }^{116} \mathrm{~A}$ five to two majority held that in making the agreement, the insured had not interfered with the insurer's subrogation rights to such an extent that it prevented the insured from relying on his or her contract of insurance. ${ }^{117}$ Arriving at this decision, the Court discussed the public policy concerns surrounding the extinguishment of the insurer's right to subrogate. Writing for the majority, Justice Iacobucci cited the words of Professor Craig Brown with approval:

[M] ost observers consider the cost-saving rationale of subrogation to be insignificant at best and that, in fact, a successful recovery in a subrogation claim is really a windfall for an insurer. ${ }^{118}$

Justice Iacobucci went on to conclude that, while the value of an indemnity payment is significant to the insured,

subrogation rights against underinsured or uninsured drivers are rarely very valuable at all ... In view of the near-negligible value of the subrogation right, it would be overreaching, in my view, to regard its loss as significantly changing the insurer's position. The risk that the insurer has assumed is effectively compensated for by the insured's monthly premium. Without being cynical, I would be very surprised indeed if the loss of a subrogation right with little practical value were significant enough to have any effect whatever upon the insurer's balance sheet. The insurer is free to set premiums at such a level as to ensure that its risk is covered, exclusive of the anticipated value of subrogation rights, and I would cautiously presume that this is precisely what it has done. ${ }^{119}$

Gilles, supra note 77 at 684 .

Derham, supra note 12 at 153; Billingsley, supra note 10 at 927.

Somersall, supra note 17; Canadian Bar Association (CBA), "Somersall v. Friedman: Despite insured's settlement, claim can proceed," online: CBA <http://www.cba.org/cba/newsletters/ins-2003/PrintHtml. aspx?DocId $=11545>$.

Somersall, ibid at para 6.

Ibid at para 65.

Brown \& Donnelly, supra note 16, ch 13 at 30 cited in Somersall, supra note 17 at para 71. Somersall, ibid 17 at paras 71-72 [emphasis added]. 
While it is questionable whether the facts of Somersall provided the proper evidentiary foundation, ${ }^{120}$ Justice Iacobucci's comments raise important considerations for assessing the cost-saving potential of subrogation in the context of impaired driving. Particularly relevant is the fact that Somersall involved an underinsured motorist. The situation is akin to subrogation by an insurer against its own insured because, in both cases, the individual has either exhausted or lost the protection of their own third party liability coverage. Thus, Justice Iacobucci's assertion that "subrogation rights against underinsured or uninsured drivers are rarely very valuable at all”121 presumably applies to Alberta's former system of section A coverage for impaired drivers. Also noteworthy is the suggestion that automobile insurers do not account for potential recoveries through subrogation when setting premiums. ${ }^{122}$ If this speculation is accepted, then the economic advantage of subrogation over Alberta's current approach to section A coverage of impaired drivers may be insignificant.

The dissenting judgment of Justice Binnie clouds this issue. ${ }^{123}$ In contrast with the majority's view on the value of subrogation rights, Justice Binnie was of the opinion that subrogation plays a significant role in determining the cost of insurance:

The insurance industry does not, I think, spend millions of dollars a year pursuing subrogated claims out of an academic interest in avoidance of over-compensation of insureds or a morality crusade against wrongdoers. They do so in the expectation of recovering a significant portion of their losses from wrongdoers to reduce their overall loss experience on which the calculation of premiums is ultimately based. If subrogation litigation were of "near-negligible value" the insurers, being professional in these matters, would not engage in it. A risk with recourse against the wrongdoer is different than a risk without such recourse. $^{124}$

It is clear that Justice Binnie did not regard recoveries through subrogation as a "windfall” for insurers. ${ }^{125}$ Rather, subrogation was framed as having the potential to fundamentally alter the nature of the risk insured against and, consequently, the premiums charged. Pursuant to this characterization, Alberta's current third party liability scheme would be less economical compared to the prior system, which permitted subrogation.

Ultimately, without numbers, it is not possible to determine which approach better fulfills the cost-saving objective of subrogation. The majority of the Supreme Court of Canada views subrogation rights as having a "near-negligible" value upon which the calculation of premiums does not depend. ${ }^{126}$ Yet, as Justice Binnie notes, the long-standing existence of this right, and the amount of money spent exercising it, would suggest that the monetary justification for subrogation is more than theoretical. Without being able to resolve this issue, it is important to note that the objectives of subrogation should not be considered in isolation. To this end, a persuasive argument may lie in the fact that any increases in third party liability insurance are shouldered by potential victims. ${ }^{127}$ In other words, if drivers in Alberta 
are indeed paying higher premiums as a result of the elimination of subrogation, they are doing so having gained the right to timely, upfront compensation in the event that they themselves are injured by an impaired driver. Finally, any economic analysis of subrogation in this context must be conditional on the current state of civil judgments against impaired drivers in Alberta. If Alberta courts begin awarding punitive damages in such cases, the threat of frequent, unpredictable awards could require insurers to increase their reserves, and consequently, their premiums. ${ }^{128}$

\section{CONCLUSION}

While the complexity of automobile insurance and the multitude of interests it serves precludes a perfect solution, it is clear that Alberta's current approach to third party liability coverage for impaired drivers adequately satisfies the objectives of subrogation. Like the former system, this current section A scheme aims to provide third party victims of impaired driving with upfront compensation. However, if one accepts the practical concerns of subrogation identified by the legislature, the current system appears better suited to delivering timely payment without the added expense of litigation. The current system similarly prevents the victimization of the insured's dependents, whose financial wellbeing might otherwise be jeopardized by the insurer's subrogated recovery. Admittedly, the removal of the insurer's right to subrogation has substantially weakened the insurance consequences of impaired driving. Instead of shouldering the financial burden of the third party judgment, impaired drivers risk increased premiums and a denial of certain section B and $\mathrm{C}$ benefits. However, a closer examination of the deterrence argument underpinning the loss-shifting rationale of subrogation suggests that the threat of civil liability is unlikely to prevent individuals from driving while impaired. For those insureds that do, serious regulatory and criminal penalties await. Weighing these considerations, Alberta's current system of third party liability coverage appears more consistent with the second objective of subrogation. From an economic perspective, the lack of quantitative evidence does not allow for a determination on the relative advantages of the prior and current system. However, a majority of the Supreme Court of Canada has expressed considerable doubt as to whether subrogation actually fulfills its cost-saving justification. Considering the three objectives of subrogation together, the most that can be said at the present time is that the current system satisfactorily fulfills the policy goals of the pre-amendment approach to section A coverage of impaired drivers. These objectives, however, should not be looked at in isolation. As with the clear prioritization of victim compensation by the legislature, the practical realities of impaired driving may demand that these factors be given different weight.

In the end, however, a thorough analysis of the merits of Alberta's approach to this issue since 1982 must extend beyond the policy assessment provided in this article. Empirical evidence is necessary to contextualize the pertinent considerations associated with the insurability of impaired drivers. Given the lack of materials available on this topic and the general complexity of automobile insurance legislation, it is likely that many Albertans are unaware of the current or past status of third party liability coverage for impaired drivers. Further exploration of this issue will enable the public, the insurance industry, and the legal profession to contribute to a meaningful discourse on the future direction of insurance 
legislation - a discussion that may take on added importance in a changing climate for tort claims against impaired drivers. A deeper understanding of subrogation in practice will also ameliorate the initial appearance of injustice inherent to the idea of shielding impaired drivers from civil liability. 